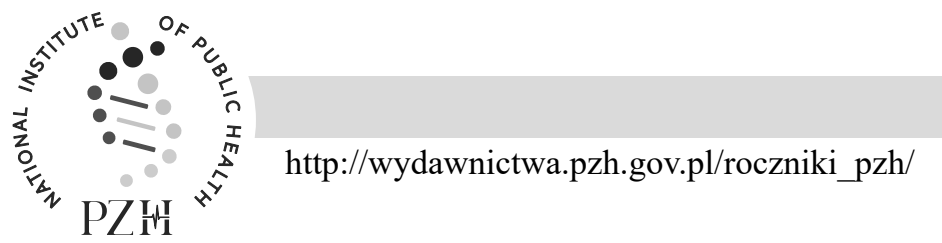

\title{
NATURAL GROUNDWATERS IN POLAND - OCCURRENCE, PROPERTIES AND CHEMICAL TYPES*
}

\author{
Joanna Ziemskal, Małgorzata Mazańskal, Tomasz Szynal', Jolanta Solecka \\ ${ }^{1}$ National Institute of Public Health - National Institute of Hygiene, \\ Department of Environmental Health and Safety, Chocimska 24, 00-791 Warsaw, Poland
}

\begin{abstract}
Chemical composition, organoleptic and physicochemical properties of natural groundwaters are varied and dependent on their geological environment. Determining the basic organoleptic properties - such as colour, taste, odour - as well as physical properties - such as electrical conductivity or redox potential - allow us to assess the stability of water chemical composition. Based on their origin, groundwaters can be divided into infiltration, as well as condensation, juvenile, metamorphic and relic groundwaters, which are currently of lesser value. Groundwaters sourced in Poland belong to various chemical types and play an important role in balneotherapy and the bottling industry. Of particular importance are thermal, bicarbonate, chloride or sulphate type waters. There is also a growing interest in humic waters found in the Wielkopolska region.
\end{abstract}

Key words: infiltration waters, thermal waters, electrical conductivity of water, humic waters, chemical types of water

\section{STRESZCZENIE}

Skład chemiczny, właściwości organoleptyczne i fizykochemiczne naturalnych wód podziemnych są zróżnicowane i uwarunkowane środowiskiem geologicznym, z którego pochodzą te wody. Określenie podstawowych właściwości organoleptycznych, takich jak barwa, smak, zapach, a także fizycznych jak np. przewodność elektryczna czy potencjał redoks pozwalają ocenić stałość składu chemicznego wody. Wody podziemne ze względu na ich pochodzenie można podzielić na infiltracyjne, a także kondensacyjne, juwenilne, metamorficzne i reliktowe, mające obecnie mniejsze znaczenie. Wody podziemne wydobywane na terenie Polski należą do różnych typów chemicznych i odgrywają ważną rolę w balneoterapii i przemyśle rozlewniczym. Szczególne znaczenie mają wody termalne, wodorowęglanowe, chlorkowe czy siarczanowe. Rosnące zainteresowanie budzą również wody humusowe występujące na terenie Wielkopolski.

Słowa kluczowe: wody infiltracyjne, wody termalne, przewodność elektryczna wód, wody humusowe, typy chemiczne wód

\section{INTRODUCTION}

Water is one of the most important substances that can be found in nature. It is necessary for hydration; thus, it is life-sustaining and constitutes a substantial and major constituent of a living cell in terms of weight $[23,26]$. Most physiological, chemical and physicochemical processes occurring in living organisms involve water. Waters present on the Earth can be divided into three basic groups, depending on their location (atmosphere, hydrosphere and lithosphere). These include atmospheric waters, surface waters and groundwaters [21,22].
Particularattentionneeds to bepaid to groundwaters. According to the definition provided in the Water Law Act of 20 July 2017, groundwaters are understood as all the waters located under the Earth's surface within the saturation zone, including groundwaters that remain in direct contact with the ground and the substratum [17, 37]. In the previous definition set forth in the Water Law Act of 18 July 2001, groundwaters were waters occurring under the earth's surface in free cavities of the earth's crust's rocks, which create depending on the water depth - near-surface or deeper usable aquifers [36].

A scientific field that is concerned with groundwaters is called hydrogeology (Greek: hýdōr

Corresponding author: Joanna Ziemska, National Institute of Public Health - National Institute of Hygiene, Department of Environmental Health and Safety, Chocimska 24, 00-791 Warszawa, Poland, tel. +48 225421 319, e-mail: jziemska@pzh.gov.pl

* This article is also available in Polish version on the journal's website

(C) Copyright by the National Institute of Public Health - National Institute of Hygiene 
- water, ge - ground, logos - science). It deals with studying their origin, physicochemical properties, distribution and movement within the earth's crust. The aim of hydrogeological studies is knowing the quality and quantity of groundwaters occurring in various geological formations, explaining the origin of those waters and determining the potential of their use for economic, industrial or health purposes [10].

Groundwaters are also studied by balneology, in order to determine their potential use in various forms of therapeutic treatments: drinking therapy, inhalation or bathing.

\section{ORIGIN AND DIVISION OF GROUNDWATERS}

In terms of origin, groundwaters can be divided into infiltration, condensation, juvenile, metamorphic and relic waters (Scheme 1) [10,21,38].

Infiltration waters are groundwaters that owe their existence to penetration (infiltration) of atmospheric precipitation deep into the earth's crust. The amount of water penetrating the rocks mainly depends on the amount of precipitation and the size of chasms and pores in the rocks. The more cracks, pores and other cavities in rocks, the greater is the permeability of grounds and rocks, i.e. their ability to conduct water. The amount of precipitation waters penetrating the rocks depends on the lay of the land - the more diverse the land, the greater is the surface runoff and the less waters infiltrate the rocks. Negative factors influencing the volume of infiltration waters are evaporation and related temperature and humidity. The evaporation rate in the air is rising along with rising temperature. Humid air lowers or stops water evaporation and then it is conducive to infiltration [21]. Vegetation present on a given land as well as the geographical position of the area where the water occurs also have a significant impact on the amount of precipitation water. Dense vegetation inhibits surface runoff of the water and stores it in-between the roots, creating better conditions for infiltration. Infiltration waters flowing through the rocks become mineralised, although usually these are low-mineralised waters. Infiltration waters are used to supply people with drinking water. They are usually treated with aeration and filtration processes in order to give them acceptable organoleptic properties (lack of sedimentation, colour, smell). In certain regions of Poland, e.g. Opole, Busko or Nowy Korczyn, infiltration waters are very high in iron compounds, while in the region of Tarnobrzeg, they are characterised by unstable physicochemical composition. This might necessitate more advanced processing to make them suitable for consumption by people [16].

The infiltration waters can be contaminated by pollution from the ground environment, which should be controlled and removed before using this type of water to supply the population.

Condensation waters are groundwaters formed through condensation of water vapour present in the air filling the pores and cavities in the soil, grounds and rocks. Probably, there are more condensation waters in those areas where there are strong temperature fluctuations in the near-surface layers as well as on deserts, where at night the ground cools down faster than the air. In oceanic climates, the role of condensation in groundwater formation is probably small.

Juvenile (magmatic) waters are groundwaters formed at the last stage of magma solidification as it travels towards Earth's surface. In the light of contemporary opinions, only a small amount of groundwater is of magma origin [10]. Relic waters are

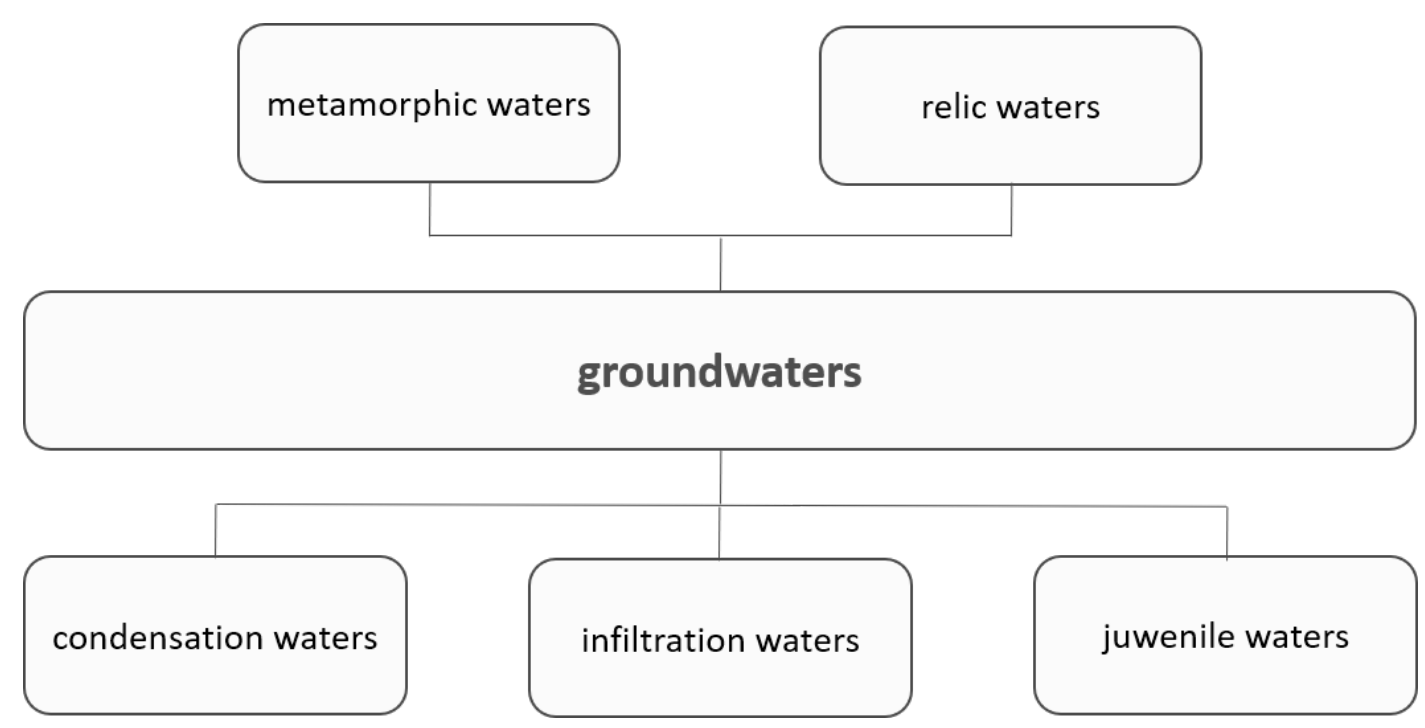

Scheme 1. Division of groundwaters in terms of their origin 
defined as waters occurring in the zone of impeded exchange, with a very long residence time in the rock medium [1]. Metamorphic waters are formed during thermal rebuilding of perishable minerals [38].

\section{PHYSICAL, PHYSICOCHEMICAL AND ORGANOLEPTIC PROPERTIES OF GROUNDWATERS}

Correct determination of groundwater physical, physicochemical and organoleptic properties allows a preliminary identification of the water type and its potential impurities. Water physical and physicochemical properties include temperature, $\mathrm{pH}$, radon level and electrical conductivity. Organoleptic properties, on the other hand, are colour, turbidity, taste and odour. These properties depend on numerous factors, including geological environment of the water and its depth. Discussed below are selected physical, physicochemical and organoleptic parameters of groundwaters.

\section{Temperature of groundwaters}

In the latitude of Poland, shallow waters are $5-12^{\circ} \mathrm{C}$. From larger depths, waters are obtained the temperature of which can be even up to several dozen Celsjus degrees .

Groundwater temperature is influenced by such factors as geothermic level (depth expressed in metres where temperature rises by $1^{\circ} \mathrm{C}$ ), the depth of occurrence of the water resources, mean annual air temperatures, period air temperature fluctuations within a given area, water flow rate and rock thermal conductivity. Groundwater temperature determines the course of hydrogeochemical processes [21,22].

Temperature-based groundwater division can use the hydrogeological or balneological criterion.

Hydrogeological division distinguishing cool waters $\left(\mathrm{t}<\mathrm{t}_{\text {mean }}\right)$, ordinary waters $\left(\mathrm{t}=\mathrm{t}_{\text {mean }}\right)$ and warm waters $\left(t>t_{\text {mean }}\right)$ is based on the criterion of mean annual air temperature of this area where the given groundwaters are present [21].

Balneological division is based on the ratio of water temperature to human body temperature and the impact of different water temperatures on human body. Cool waters $\left(\mathrm{t}<20^{\circ} \mathrm{C}\right)$ and thermal waters $(\mathrm{t}>$ $20^{\circ} \mathrm{C}$ ) are distinguished. What is more, thermal waters are divided into:

- hypothermal, $\mathrm{t}=20^{\circ} \mathrm{C}-35^{\circ} \mathrm{C}$

- homeothermal, $\mathrm{t}=35^{\circ} \mathrm{C}-40^{\circ} \mathrm{C}$

- hyperthermal, $\mathrm{t}>40^{\circ} \mathrm{C}[21]$

Waters of natural origin - i.e. underground origin - with a noticeable higher temperature at their outflow point are referred to as a thermal spring or geothermal waters [12]. In the recent years, many new sources of this type of waters have been found in Poland. They are very diverse in terms of temperature and chemical composition [11,14]. Their mineralisation ranges from $0.15 \mathrm{~g} / \mathrm{dm}^{3}$ to $135 \mathrm{~g} / \mathrm{dm}^{3}$ and temperature from $20^{\circ} \mathrm{C}$ to $86^{\circ} \mathrm{C}$. Dominating components of geothermal waters in Poland are usually chloride and sodium ions, but also sulphate carbonate, calcium and magnesium ions. Besides them, there are also various levels of components with specific biochemical properties, including ferrous, iodide and fluoride ions, radon, as well as sulphate compounds (II) [14,28]. Geothermal waters have been recognised as the first natural spa resources $[9,12]$.

In Poland, thermal waters are commonly found in the three major regions: Polish Lowland, Sudetes and Carpathians. Based on observations conducted by Chowaniec et al., it can be concluded that the best conditions for sourcing thermal waters in the Carpathian Mountains are within the Podhale Basin due to: favourable geological structure, high temperature (up to $86^{\circ} \mathrm{C}$ at the outflow), low mineralisation (up to $3 \mathrm{~g} / \mathrm{dm}^{3}$ ), high efficiency (even more than $200 \mathrm{~m}^{3} / \mathrm{h}$ from a single spring), renewability and easy land access [4].

Geothermal energy and be used directly for heating, leisure and balneology purposes, as well as agriculture, fishkeeping or thermophilous animal species. It is currently used in 78 countries of the world, although China, USA, Sweden, Turkey and Japan account for $55 \%$ of the total annual global use of geothermal heat [28]. Polish thermal waters are diverse in terms of temperature, therefore their use should especially be restricted to heating, preparation of hot utility water, as well as leisure and balneology. However, it is rather improbable that they will constitute an electrical energy source in the near future [20].

\section{Electrical conductivity of groundwaters}

Water is a solution of electrolytes that conduct electricity. Electrical conductivity is one of the characteristic features of groundwaters and depends on the valence of all the free ions. Divalent ions can carry twice as much a charge than the same number of univalent ions. The determination of conductivity is of practical importance as it is one of the methods of detecting changes in the physicochemical state of water [27]. Therefore, it can be a simple indicator of stability or variability of water chemical composition in control testing of groundwaters [11]. Water electrolytic conductivity expressed in $\mu \mathrm{S} / \mathrm{cm}$ roughly corresponds to water mineralisation expressed in $\mathrm{mg} /$ $\mathrm{dm}^{3}$ [27]. It must be remembered, though, that the presence of surface-active substances in water, and 
another compounds like oils, greases, tars, might falsify the results due to contaminating the electrode of the testing equipment.

\section{Oxidation-reduction potential of groundwaters}

It is one of the factors that is largely determined by the chemical composition of groundwaters. It measures the ability to transfer (return or accept) electrons by ions, molecules, and solid phases participating in a reaction. It is an index parameter based on the presence of specific concentrations (activities) of all the components involved in the oxidation-reduction reactions in the solution [8]. Both water $\mathrm{pH}$ and oxidation-reduction potential (also known as redox potential, Eh) are values that change when the water comes in contact with the external environment. Hence, determining a water's redox potential should happen right after it flows to the surface or in as short a time after sampling as possible before iron hydroxide (III) forms. Redox potential depends on $\mathrm{pH}$ and temperature and is also influenced by the oxidation number of polyvalent elements, as well as the content of some organic compounds that, by oxidation, constitute a source of $\mathrm{CO}_{2}$ [34]. The presence of $\mathrm{CO}_{2}$ in groundwaters allows them to keep a low redox potential. In waters with a low redox potential, ions such as iron and manganese, remain at a low oxidation number, which makes them better absorbed by the body [5].

\section{Colour of groundwaters}

Groundwaters are usually colourless. Groundwater colour can be caused by the content of certain organic or mineral compounds, or mechanical suspensions. The most frequent cause of natural water colour (yellow or brownish) is the scouring of humic substance and other products of plant material decomposition from the substrate. The greatest role in this process is attributed to humic and fulvic acids, which are highmolecular-weight substance with numerous function groups. Bluish-green colour of water might indicate the presence of acidic iron salts (such as sulphates), while rust colour might indicate the content of trivalent iron compounds [2,21,22].

Water colour is determined using platinumcobalt or dichromate-cobalt standard solutions by comparing water samples with the standards. Colour determination should be performed immediately after a sample is taken.

\section{Turbidity of groundwaters}

Turbidity is an optical property of water, which involves scattering and adsorbing some of visible spectrum by particles dispersed in water. The most common causes of water turbidity are the presence of sand, insoluble carbonates, iron hydroxide, organic substances or microorganisms. Clear groundwater might become significantly turbid after flowing out to the surface and being exposed to air. This is caused by the release of natural carbon dioxide and then precipitation of iron hydroxide or calcium carbonate. Turbidity determination should be performed immediately after sampling water from a spring $[2$, $10]$.

\section{Odour of groundwaters}

Groundwaters are usually odourless. Waters having a less or more intensive odour are frequently those sourced from shallow layers that come in contact with swamps, marshes and moors, as well as waters contaminated with municipal or industrial sewage. There are five degrees of odour intensity - just like taste intensity. Water at three degrees is not suitable for consumptions, while at higher degrees it cannot be used even for household purposes.

Due to the origin, several types can be distinguished:

1. Odours of natural origin, which are divided into three groups:

a) Plant odours caused by organic compounds, which are not subject to decomposition (smell of earth, peat, moss, tree bark, etc.),

b) Decay odours caused by organic substances subject to decomposition (stale, decayed, etc.),

c) Odours associated with the presence of natural inorganic water components (e.g. hydrogen sulphide)

2. Specific odours of unnatural origin caused by the contamination of groundwaters mainly by sewage, e.g.: chloric, phenolic [10].

\section{Taste of groundwaters}

Groundwater taste frequently depends on their mineralisation. Highly mineralised waters (containing $>1500 \mathrm{mg} / \mathrm{dm}^{3}$ of dissolved substances) often has a distinctive taste, e.g. salty taste can be caused by the content of sodium chloride. Bitter taste, on the other hand, can come from sodium and/or magnesium sulphates, while alkaline taste can come from the dominant amount of sodium, calcium, and magnesium bicarbonate [13]. Excessive content of carbon dioxide gives water sour and stinging taste, which is why waters containing more than $250 \mathrm{mg} \mathrm{CO} / \mathrm{dm}^{3}$ are referred to as carbonic acid waters. 


\section{CHEMICAL TYPES OF GROUNDWATERS}

Chemical composition of waters largely depends on the composition of the earth's crust layers in which they form and through which they are flowing. Mineral components, such as calcium, magnesium, sodium, potassium, iron, manganese, ammonium ion, chlorides, bicarbonates, fluorides, iodides, sulphates, sulphides are accompanied by non-ionic components: orthoboric and metasilicate acids. Groundwaters also contain gases, such as carbon dioxide, hydrogen sulphide or radon. Waters naturally saturated with carbon dioxide in a larger concentration usually contain a certain amount of carbon dioxide bound in the form of bicarbonates. Waters containing carbon dioxide in concentrations higher than $250 \mathrm{mg} \mathrm{CO} /$ $\mathrm{dm}^{3}$ are referred to as carbonic acid waters, while those containing more than $1000 \mathrm{mg} / 1$ - acidulous waters. Waters containing hydrogen sulphide are also characterised by the presence of hydrosulphides. Nitrogen and noble gases are present in waters come from considerable depths [19,21].

Apart from health-benefiting elements and compounds, groundwaters contain some trace amounts of heavy metals, including natural radioactive elements, which can have a negative impact on human body [18]. It is especially important when it comes to groundwaters used for bottled water manufacture. Natural, potentially toxic compounds that might occur in natural mineral waters include arsenic, barium, boron, lead, antimony, cadmium, mercury, chromium, copper, manganese, nickel, selenium, cyanides, fluoridesand radioactive compounds [6,15,24]. In waters made available for human consumption, including natural mineral and spring waters, maximum acceptable concentrations are determined for these components, the exceeding of which may constitute a health risk. Groundwaters in some regions of Poland, including the south-west region, are characterised by a considerable concentration of arsenic and radon from the toxicological point of view. However, appropriate procedures for preparing the water to be sold in unit packaging, including degassing and ozone aeration, allows reducing the content of these elements below the maximum acceptable limits. Some of the Polish groundwaters also contain barium and boron in concentrations higher than the maximum acceptable limits established by the Regulation of the Ministry of Health [30].

In the case of waters made available in unit packages (natural mineral and spring waters), it is permissible to remove or reduce the concentration of only some components, including arsenic, radon, fluoride, manganese, using methods proven and allowed in the applicable regulations cited above, provided that the method used does not change the concentration of other components, especially specific to a given water.

Natural components of groundwaters also include organic compounds, especially humus acids, i.e. humic, hymatomelanic and fulvic acids. A specific type of groundwaters are humic waters. Humic compounds they contain are formed in biochemical processes - condensation and polymerisation of decomposition products of plant- and animal-derived material. The aforementioned humic acids are macromolecular compounds with a poorly identified chemical structure, which can be divided depending on their solubility into:

- fulvic acids - soluble in water within the entire $\mathrm{pH}$ range

- humic acids - insoluble in water at $\mathrm{pH}<2$

- hymatomelanic acids - soluble in alcohol, insoluble in aqueous solutions with a $\mathrm{pH}<2$ [13].

Literature available so far shows that the structure of humic acids contains an aromatic core (indole, pyrimidine) and peripheral functional groups of aliphatic structure. Furthermore, fulvic, humic and hymatomelanic acids display significant differences in terms of molecular weight and molecular shape. Humic acids are compounds with a large molecular weight ranging from $50,000 \mathrm{Da}$ to $100,000 \mathrm{Da}$ and an extensive structure - a diameter of 60-100 A. Fulvic acids, on the other hand, have a molecular weight ranging from $500 \mathrm{Da}$ to $2000 \mathrm{Da}$ and a diameter of 20-30 A. Acid molecules with a larger weight show a higher affinity to bind metal ions. With a higher molecular weight and polymerisation degree, the colour intensity of humic waters also rises - from yellow (fulvic acid) to dark brown (humic and hymatomelanic acids) [15,32]. An example of intensely coloured waters in Poland are humic waters from the Miocene level within the Wielkopolska region [13].

Waters sourced from deep earth layers are generally characterised by stable chemical properties. Stable chemical composition does not mean absolutely the same concentration of particular water components, but their stable quantitative proportions [19,23]. Concentration fluctuations often depend on the size of the water intake from a given well.

Results of the determination of ions contained in tested water can be expressed in weight and equivalent concentrations. In hydrochemical practice, weight concentrations are expressed in $\mathrm{mg} / \mathrm{l}$, while equivalent concentrations in miligram equivalent in one litre of water (mval/l) [10]. One of the most frequently used qualification of mineralised and specific waters is Altowski-Szwiec qualification based on anioniccationic composition and specific component concentration. According to the qualification, water type is determined based on concentration that is no less than $20 \%$ of milligram equivalents (mval\%) of 
aggregate content of main ions - hydrogen carbonate, sulphate, chloride, calcium, magnesium, and sodium ions.

In the characterization of medicinal waters, in addition to the components that are quantitatively dominant ( $>20 \mathrm{mval} \%$ ), the names of components with specific biochemical properties are listed - if their content is equal to or higher than the established limits - also in descending order of concentration.

When determining the chemical type of water, the name of the water begins with anions and then the cations with the highest content in the water are listed in terms of milligram equivalents. Below, three main chemical types of waters in Poland are discussed (based on their quantitatively dominating anionic component).

\section{Bicarbonate waters}

Bicarbonate waters constitute a dominating type of shallow groundwaters of infiltration origin. They are used mainly for drinking water supply. Bicarbonate waters are characterised by renewability. The presence of bicarbonates is mainly caused by the dissolution of carbonate minerals and atmospheric carbon dioxide $11]$.

Due to the quantitative dominance of various cations, groundwaters in Poland belong to the following chemical types:

- bicarbonate-calcium-magnesium $\mathrm{HCO}_{3}-\mathrm{Ca}-\mathrm{Mg}$

- bicarbonate-calcium-sodium $\mathrm{HCO}_{3}-\mathrm{Ca}-\mathrm{Na}$

- bicarbonate-calcium-sodium-magnesium $\mathrm{HCO}_{3}$ $\mathrm{Ca}-(\mathrm{Na})-(\mathrm{Mg})$

- bicarbonate-sodium $\mathrm{HCO}_{3}-\mathrm{Na}$

- bicarbonate-sodium-calcium-magnesium $\mathrm{HCO}_{3}$ $\mathrm{Na}-(\mathrm{Ca})-(\mathrm{Mg})$ [11].

For example, in the town of Krynica, there are numerous groundwater intakes characterised by diverse chemical type, with $\mathrm{HCO}_{3}^{-}$always dominating among anions and $\mathrm{Ca}^{2+} \mathrm{i} \mathrm{Mg}^{2+}$ dominating among cations [6]. Bicarbonate waters are also found in other areas of Poland, for example in ŚwieradówZdrój, Szczawnica, Polanica-Zdrój, Kudowa-Zdrój, Duszniki-Zdrój, Piwniczna and Muszyna [12].

Bicarbonate waters that are most frequently used for health and spa treatments are carbonic acid waters and acidulous waters. Carbon dioxide present in the waters intensifies the process of mineral component dissolution [9].

\section{Sulphate waters}

This chemical type of waters is relatively rare within the territory of Poland. Dominating concentration of sulphates compared to other anions is usually associated with the presence of easily soluble minerals containing sulphur (e.g. gypsums and anhydrites) in the geological environment [11]. They also form in the weathering of sulphide minerals, oxidising gradually through sulphur to the sulphate form [27].

Sulphate waters containing hydrogen sulphide or sulphides in concentrations higher than $1 \mathrm{mg} / \mathrm{dm}^{3}$ belong medicinal waters and are used in balneotherapy. Sulphates in combination with other components create various types: $\mathrm{SO}_{4}-\mathrm{Cl}-\mathrm{Ca}-\mathrm{Na}, \mathrm{S}, \mathrm{SO}_{4}-\left(\mathrm{HCO}_{3}\right)-$ $\mathrm{Ca}-(\mathrm{Mg})-(\mathrm{Na}), \mathrm{S}, \mathrm{SO}_{4}-\mathrm{Cl}-\mathrm{Na}-\mathrm{Ca}-\mathrm{Mg}, \mathrm{S}$ [11].

Sulphate waters with a dominating content of sodium, i.e. $\mathrm{SO}_{4}-\mathrm{Na}$, are referred to as Glauber's water, calcium $\mathrm{SO}_{4}-\mathrm{Ca}$ - gypsum waters, magnesium $\mathrm{SO}_{4}-$ $\mathrm{Mg}$ - bitter waters, iron $\mathrm{SO}_{4}-\mathrm{Fe}$ - vitriol waters [27].

Sulphate and sulphide waters occur, among others in Busko Zdrój, Solec Zdrój, Lądek-Zdrój, Tarnów or Horyniec Zdrój [12].

\section{Chloride waters}

Chloride waters constitute a dominating type of deep groundwaters in the territory of Poland. According to observations, their mineralisation level rises along with their rising depth [11].

Chloride-sodium waters $\mathrm{Cl}-\mathrm{Na}$ - brines, form as a result of lixiviation of rock salt deposits or marineorigin sedimentary rocks. These waters also contain bromides and iodides. Apart from simple brines containing mainly chloride and sodium ions, there are also brines containing significant amounts of bicarbonate $\left(\mathrm{Cl}-\mathrm{HCO}_{3}-\mathrm{Na}\right)$, calcium $(\mathrm{Cl}-\mathrm{Na}-\mathrm{Ca})$ and magnesium (Cl-Na-Mg) ions.

In geology, brine is defined as water containing $>35 \mathrm{~g} / \mathrm{dm}^{3}$ of dissolved components, mainly sodium chloride, useful for industrial purposes. In balneology, brine is water containing more than $15 \mathrm{~g} / \mathrm{dm}^{3}$ of dissolved components with a predominance of sodium chloride. For medicinal baths it is recommended (depending on medical indications) concentration from 3 to $6 \mathrm{~g} / \mathrm{dm}^{3}$; for inhalation concentration in the range $0.9-1.5 \mathrm{~g} / \mathrm{dm}^{3}$.

An example of chloride waters are groundwaters of Rabka Zdrój. These are chloride-sodium waters with total mineralisation ranging from 17.1 to $27.8 \mathrm{~g} /$ $\mathrm{dm}^{3}$, containing a specific component - iodides, at concentrations from 12 to $20 \mathrm{mg} / \mathrm{dm}^{3}$ [29]. Chloridesodium waters are also present, among others in Ciechocinek, Kołobrzeg, Międzyzdroje, Bochnia, Goczałkowice-Zdrój or Konstancin Jeziorna [12].

\section{Acknowledgments}

This work was financially supported by the National Institute of Public Health National Institute of Hygiene in Warsaw, Poland, in the frame of project No. BK$2 / 2020$ 


\section{Conflict of interest}

The authors declare no conflict of interest.

\section{REFERENCES}

1. Baza wiedzy hydrogeologicznej - Państwowy Instytut Geologiczny Państwowy Instytut Badawczy [Hydrogeological knowledge base - National Geological Institute National Research Institute]. Available https://www.pgi.gov.pl/wody-mineralne/ (Accessed 20.10.2020) (in Polish).

2. Borczyk D.: Podstawowe parametry mające wpływ na jakość wody przeznaczonej do spożycia przez ludzi [Basic parameters affecting the quality of water intended for human consumption]. Powiatowa Stacja Sanitarno-Epidemiologiczna w Wieluniu, Available https://pssewielun.pl/pliki/akt_150806_podstawowe parametry_wody.pdf (Accessed 20.10.2020) (in Polish).

3. Carstea E.M., Levei E.A., Hoaghia M.A., Savastru R.: Quality assessment of Romaniam bottled mineral water and tap water. Environ Monit Assess. 2016;188:521-535

4. Chowaniec J., Poprawa D., Witek K.: Występowanie wód termalnych w polskiej części Karpat [Occurrence of thermal waters in the Polish part of the Carpathians]. Prz Geol. 2001;49(8):734-742 (in Polish).

5. Drobnik M., Latour T: Badania wpływu procesów technologicznych $\mathrm{w}$ toku produkcyjnym wód butelkowanych na ich właściwości utleniającoredukcyjne [The effect of technological processes in bottled water production on its redox properties]. Rocz Panstw Zakl Hig 2003;54(3):275-285 (in Polish).

6. Ciężkowski W., Kozłowski J.: Typy chemiczne wód podziemnych Krynicy. [Chemical types of grounwaters from Krynica]. Prz Geol. 1999;47(6):560-563 (in Polish).

7. Directive 2009/54/EC of the European Parliament and of the Council of 18 June 2009 on the exploitation and marketing of natural mineral waters. Official Journal of the European Union; 26.6.2009; L 164/46

8. Dobrzyński D., Kmiecik E., Wątór K.: Potencjał utleniająco-redukcyjny - informatywny i niewykorzystany wskaźnik jakości wód leczniczych i mineralnych [Oxidation reduction potential - an informative and unused indicator of curative and mineral water quality]. Acta Balneol. 2018;4(154):233-238 (in Polish).

9. Dowgiatto J., Kleczkowski A.S., Macioszczyk T., Różkowski A. Słownik hydrogeologiczny [Hydrogeological dictionary]. Państwowy Instytut Geologiczny, Warszawa, 2002 (in Polish).

10. Elbanowska H, Zerbe J., Siepak J.: Fizyczno-chemiczne badania wód [Physico-chemical testing of waters]. Wydawnictwo Naukowe UAM, Poznań, 1999 (in Polish).

11. Felter A., Skrzypczak L., Socha M., Sokołowski J., Sosnowska M., Stożek J., Gryszkiewicz I., Wrzosek A.: Mapa zagospodarowania wód podziemnych zaliczonych do kopalin w Polsce [Map of groundwaters classified of mineral resources in Poland]. Państwowy Instytut Geologiczny, Warszawa, 2019 (in Polish).

12.Fronczyk W., Stanisławska I., Damięcka M., Jóźwik $A$.: Lecznicze zastosowanie wód wodorowęglanowych, chlorkowych oraz siarczanowych w Polsce [Therapeutic use of water bicarbonate, chloride and sulphate]. Eduk Biol Środ. 2016; 4:9-15 (in Polish).

13. Górski J., Latour T., Siepak M., Drobnik M., Sziwa $D .:$ Perspektywy wykorzystania wód intensywnie zabarwionych z poziomu mioceńskiego $\mathrm{w}$ Wielkopolsce dla potrzeb przyrodolecznictwa [Prospects of using brown water from the miocene aquifer of the Wielkopolska region for physiotherapy]. Biul Panstw Instyt Geol. 2012;452:59-66 (in Polish).

14. Kowalski J.: Hydrogeologia ogólna In: Kowalski $J$. Hydrogeologia $\mathrm{z}$ podstawami geologii [General Hydrogeology In: Kowalski J. eds. Hydrogeology with the basics of geology]. UWP, Wrocław 2007 (in Polish).

15. Krupińska I.: Problemy związane $\mathrm{z}$ występowaniem substancji humusowych $w$ wodach podziemnych [Problems associated with humic substances in the groundwater]. Zesz Nauk Uniwer Zielonogór Inż Środ. 2012;148(28):55-72 (in Polish).

16. Latour T:: Naturalne surowce lecznicze w Polsce: wody mineralne, peloidy i gazy lecznicze. In: Ponikowska I., Kochanski J.W. Wielka Księga Balneologii i Medycyny Fizykalnej i Uzdrowiskowej [Natural medicinal sources in Poland: mineral water, healing gases and peloids. In: Ponikowska I., Kochanski J.W. eds. The Great Book of Balneology, Physical Medicine and Health Resort]. Aluna, Konstancin - Jeziorna, 2017 (in Polish).

17. Latour T: Właściwości fizykochemiczne i chemiczne wód geotermalnych i ich zastosowanie lecznicze ze szczególnym uwzględnieniem wody z odwiertu PIG/ AGH-2 w Uniejowie [Physicochemical and chemical properties of geothermal waters and their therapeutic use with particular emphasis on water from the PIG/ AGH-2 well in Uniejów]. Biul Uniej. 2012;1:79-93 (in Polish).

18. Latour T: Skład chemiczny i właściwości fizykochemiczne wód naturalnych oraz warunki ich rozlewania do opakowań jednostkowych [Chemical composition and physico-chemical properties of natural waters and the conditions of their bottling into individual packages]. Źródło 2009;38:21-25 (in Polish).

19. Latour T., Drobnik M.: Właściwości biochemiczne wód geotermalnych rozpoznanych $\mathrm{w}$ Polsce określające sposób ich wykorzystania do celów leczniczych lub rekreacji [Geothermal waters recognized in Poland biochemical properties determining their usefulness for medical treatment and recreation]. Technika Poszukiwań Geologicznych Geotermia, Zrównoważony Rozwój, 2016;1:67-73 (in Polish).

20.Latour T., Drobnik M.: Pierwiastki potencjalnie toksyczne w wodach naturalnych. Uwarunkowania geologiczne. Zagrożenie dla zdrowia [Elements potentially toxic in natural waters. Geological conditions. Health hazard]. Źródło. Wody mineralne i napoje, 2006; 3: 14-16 (in Polish).

21. Maćkiewicz J., Dziubek A.M.: Kierunki rozwoju technologii oczyszczania wód infiltracyjnych [Directions of development of infiltration water treatment technologies]. Ochr Środ. 2003;4:19-22 (in Polish). 
22. Mikołajków J., Sadurski A.: Informator PSH. Główne zbiorniki wód podziemnych w Polsce [PSH Guide. Main groundwater reservoirs in Poland]. PIG-PIB, Warszawa, 2017 (in Polish).

23. Nguyen D.C.: Naturalna promieniotwórczość wybranych polskich wód mineralnych i leczniczych [Natural radionuclides of selected mineral and therapeutic waters]. Acta Balneol. 2018; 4(154):223-228 (in Polish).

24. Orłowski Z.: Balneologia ogólna [General Balneology]. Państwowy Zakład Wydawnictw Lekarskich, Warszawa, 1957 (in Polish).

25. Państwowy Instytut Geologiczny - Państwowy Instytut Badawczy. Wody termalne [National Geological Institute - National Research Institute. Thermal waters]. Available https://www.pgi.gov.pl/wody-mineralne/ przydatne/wody-termalne.html (Accessed 20.10.2020) (in Polish).

26.Pazdro Z:: Hydrogeologia ogólna [General Hydrogeology]. Wydawnictwa Geologiczne Warszawa, 1977 (in Polish).

27. Ptochniewski Z.: Hydrogeologia [Hydrogeology]. Wydawnictwa Geologiczne, 1971 (in Polish).

28. Qattrini S., Pampaloni B., Brandi M.L.: Natural mineral water: chemical characteristics and health effects. Clin Cases Miner Bone Metab. 2016;13(3):173-180

29. Rajchel L.: Występowanie i wykorzystanie wód chlorkowych Rabki Zdroju [Occurence and utilisation of chloride waters in Rabka Zdroj]. Geologia 2009; 35(2):271-279 (in Polish).

30. Rozporządzenie Ministra Zdrowia z dnia 31 marca 2011r. w sprawie naturalnych wód mineralnych, wód źródlanych i wód stołowych Dz. U. 2011, nr 85, poz.
466 [Regulation of the Minister of Health of 31 March 2011 on natural mineral waters, spring waters and table waters. Journal of Laws of 2011, No 85, item 466] (in Polish).

31. Satora S., Chmielowski K., Watęga A.: Balneologiczne wykorzystanie wód podziemnych w wybranych rejonach Polski południowej [Balneological use of groundwater in selected regions of southern Poland]. Acta Sci. Pol., Formatio Circumiectus 2010;9(4):43-53 (in Polish).

32. Schnitzer M.: Organic matter: Principles and processes. Encyklopedia of soils in the environment, 2005:85-93 doi.org/10.1016/B0-12-348530-4/00208-3

33. Sengupta P.: Potential health impacts of hard water. Int J Prev Med. 2013;4(8):866-875

34.Szmytówna M.: Balneochemia. Chemia wód mineralnych i peloidów w Polsce [Balneochemistry. Chemistry of mineral waters and peloids in Poland]. PZWL, Warszawa, 1970 (in Polish).

35. Tomaszewska B., Szczepański A.: Possibilities for the efficient utilisation of spent geothermal waters. Environ Sci Pollut Res. 2014; 21:11409-11417

36. Ustawa Prawo wodne z dnia 18 lipca 2001r. Dz. U. $2001 \mathrm{nr} 115$, poz. 1229 [Act of 18 July 2001, Water Law. Journal of Laws of 2001, No 115, item 1229] (in Polish).

37. Ustawa Prawo wodne $\mathrm{z}$ dnia 20 lipca 2017r., Dz. U. 2017, poz. 1566 [Act of 20 July 2017, Water Law. Journal of Laws of 2017, item 1566] (in Polish).

38. White D. E.: Magmatic, connate, and metamorphic waters. Geol Soc Am Bull. 1957;68:1669-1682

Received: 09.10.2020

Accepted: 12.11.2020 